\author{
Wasyl Bilczak \\ University of Warmia and Mazury in Olsztyn \\ e-mail: wasyl.bilczak@uwm.edu.pl \\ ORCID: 0000-0002-8112-2389
}

\title{
DEVELOPMENT OF SPATIAL AND INTERDISCIPLINARY RESEARCH IN THE RUSSIAN REGIONS
}

\section{ROZWÓJ PRZESTRZENNYCH \\ I INTERDYSCYPLINARNYCH BADAŃ \\ W REGIONACH ROSYJSKICH}

DOI: $10.15611 / \mathrm{pn} .2019 .9 .01$

JEL Classification: P40, R10

Summary: The article discusses the interdisciplinary approaches to the study of regional economic systems and an integrated approach to the theory and methods of spatial development in spatial progress analysis. In addition, the administrative and the reproduction approaches of scientists to the assessment of specific territorial entities are analysed. Attention is paid to the manifestation forms of the reproduction stages with a complete cycle. Examples of specific national systems' development and political institutions are considered ed, and also the important processes directly impacting on the regionalization are highlighted. For example, economic disciplines characterize the region as spatial, socio-economic integrity, where the main processes of material production take place and the integrity of the reproduction base is preserved. The approaches of various scientific disciplines in the research on regional economic systems and specific recommendations for their development are shown.

Keywords: interdisciplinary research, complex research, regional economic systems, spatial development, territorial development, "region" category, regionalization.

Streszczenie: W artykule omówiono aspekty gospodarki przestrzennej, które są częścią badań systemowych, skoncentrowanych na pomiarze efektów ekonomicznych w przestrzeni i osiąganiu ogólnej równowagi społecznej. Zwraca się uwagę na metody zagospodarowania przestrzennego, jak również na formy manifestacji etapów reprodukcji z pełnym cyklem. Dziś problemy regionalne wymagają większej uwagi, gdyż gospodarka przestrzenna staje się głównym przedmiotem stosunków gospodarczych i politycznych. W tej sytuacji ważne jest określenie specyfiki i priorytetów badań interdyscyplinarnych regionów, opartych na przewagach komparatywnych regionu, cechach jego rozwoju historycznego i kulturowego. W związku z tym artykuł bada interdyscyplinarne podejście do oceny rozwoju heterogenicznych formacji terytorialnych. Przedstawia podejścia różnych dyscyplin naukowych w zakresie zarówno badań regionalnych systemów gospodarczych, jak i konkretnych wniosków do podejmowania decyzji zarządczych.

Słowa kluczowe: badania interdyscyplinarne, badania kompleksowe, systemy regionalno-gospodarcze, rozwój przestrzenny, rozwój terytorialny, region, regionalizacja. 


\section{Introduction}

The latest scientific literature pays great attention to the regional issue. A lot of interesting new research occurred showing the increased interest of science in complex, interdisciplinary research on specific territorial entities. A region is a heterogeneous and multifaceted research object for economics. A very important area is spatial economics, which is an important tool aimed at researching and measuring the effects of managing and achieving a general social equilibrium in economic systems. It represents the most important concept of the study of social-economic relations and reflects the complexity of real social systems, localized within the boundaries of specific territories (regions). In addition, spatial economics allows to analyze in detail all the elements of regional economic systems.

Interdisciplinary research is also a critical area of focus, based on the postulates of spatial economics and explore regional systems in terms of a specific scientific discipline. Interdisciplinary findings are highly valuable for the development of scientific methodology. To build an effective socio-economic state policy it is necessary to have clear knowledge and concepts of the features and specifics of the individual territories development. Therefore, high-quality interdisciplinary research on regional issues based on a spatial approach is the key to the successful development of the country.

The purpose of the study is to show the critical importance of spatial and interdisciplinary research on the development of regional economic systems using the example of the Russian scientific school.

The methodological basis of the study is the fundamental principles of spatial economics and the multidisciplinary conclusions of the theory of regional economics using functional, systemic and structural approaches.

\section{Spatial methods of regions research}

The spatial approach is an important method of exploring the regions. The formation of a single economic space and the transformation processes of the economy and its current associated transition to an innovative development model, require additional analysis and specific theoretical research on this important issue.

It should be noted that there are very important and significant studies of Western European scientists on the problems of spatial economics. Starting from the founder of the agricultural location theory J.H. Thünen [1826], followed by Engelbrecht in the field of spatial agrarian economics, and in particular Carl Wilhelm Friedrich Launhardt in whose work the ideas of agricultural location were spread first regarding the siting of industrial enterprises. Next A. Weber elaborated the theory of Thünen and Launhardt and introduced, in addition to transport costs, general production costs, which made it possible to place the production of a particular product at the most advantageous point in the economic space [Weber 1909]. 
The next most important theory of spatial economics is the Christaller's central place model [Christaller 1933] of location within the hexagons industries siting and resettlement in consuming their products. A significant contribution to the theoretical base development of the spatial behaviour of economic agents was made by A. Lösch [1940]. He associated the behaviour of economic agents with the functioning of a holistic market environment, in which enterprises are oriented not only on profit but also on their market niche protection from other competitors. Such distinguished scientists as F. Perroux and J. Boudeville [Perroux 1950], introduced concepts and formulated ideas about polarized economic development and centres of attraction. T. Hägerstrand developed the theory of spacial diffusion of innovations [Hägerstrand $1952 ; 1967]$. Significant work on the main areas and network areas has appeared.

On the other hand, the functioning of space is considered in the time aspect by K. Menger and A. Marshall, who for the first time included "time" in the theoretical constructions of spatial economics. The main merit of A. Marshall, as R.L. Heilbroner wrote, was his "introduction" of the time measurement theory as a critical component in the search for balance [Heilbroner 1999]. The same problems were investigated by F.A. Hayek [2008] and many other scientists. The scientific literature has extensive materials by Western European schools of spatial economics. The largest contribution to these studies was made by German and French (continental) scientists, as well as Anglo-Saxon schools of science.

This study aims to introduce the young school of the Russian spatial economy in the context of regional economic systems. Therefore, it seems that the West European scientific schools of spatial economics deserve a detailed and separate publication.

Unfortunately very often one can find in the economic literature that space is compared with territory. Space, including the economic one, is universal regarding the development of the entire economic life of a person. If space consists of the earth's territory, the atmosphere and water areas where full cycles of human reproduction and life are carried out, the term 'territory' is a narrower specialized concept. These can be landscape territories, territories of large economic entities, transportation hubs, ports, the largest industries and others. A significant obstacle here can be the uncertainty with the formulation of a specific topic and structure of the object of study.

Due to this, there is more interest in the scientific approach to economic space. "Space is a set of relations expressing the coordination of material objects, their location as to each other and the relative value (distance and orientation). Space expresses the order of location of simultaneously existing objects and their length. Time is a set of relations expressing the coordination of successive states (phenomena), their sequence and duration" [Physical Encyclopedic Dictionary 1965, p. 227].

As can be seen from the definition, one is talking about economic life (the coordination of material objects and their location relative to each other) and time which expresses the totality of its coordination, sequence and duration. In many surveys, the region appears as spatial integrity with a specific production structure per unit of space and time, where time is always explored in conjunction with space. 
Thus in indigenous science, there is a significant work of O.A. Biiakov "The Theory of Economic Space: Methodological and Regional Aspects" [Biiakov 2004, p. 152], according to whom economic space consists of three established approaches: territorial, resource and informational.

The author gives a concrete - based on extensive analytical material - assessment of the spatial approach. Without going into detail, one should note that the spatial economic environment is closely related to the social and economic processes that business entities carry out in a particular territory. This is how economic space is formed within territorial boundaries. The transformation of the economy and the search for new ways of development establish certain interrelations in the territorial location of business entities. Thus, the territorial approach to economic space still seems relevant and universal.

Resource potential regarding the concept of economic space is methodologically wrong. Since it is connected with the redistribution of resources in which all business entities are involved, it is then that the object to which the actions of the subjects are directed is replaced. Usually, the economic process acts as an object of interaction for all business entities. If previously, science studied the effective way of transforming the available resources, now it is exploring the effective use of accumulated knowledge and the rational use of human capital. This transition to a different development paradigm is based on information and knowledge.

The informational approach to the definition of an economic space is formed on information flows that influence the development of economic space, as well as on information exchange between economic entities. Since the main elements forming the economic space are the cumulative economic process, economic time and economic competition, the information approach has a significant impact on the development of the regional economy.

Great importance has been given to research on identifying the factors which determine the configuration of the regional economic space, based on the process characteristics of using the criteria for assessing the potential of a region. The classical approach to modelling processes in the economic space has been developed by science.

In the economic literature, as already noted, there are many approaches to the theory and methods of spatial development, where economic space is determined on the basis of its heterogeneity and unevenness of economic development, as well as modelling of the placement of activities and organization of space [Limonov (ed.) 2014]. Moreover, the study examines the dynamics of regional differences by the level of socio-economic development and the spatial development of the Russian territories through a large amount of factual material.

It should be emphasized that the territory occupies a dominant position in the economic space and contains a number of objects and connections between them: settlements, industrial enterprises, economically developed and recreational areas, transport and engineering networks, etc. 
The regional approach in the economic space is used in the work "Regional Economy" [Plisetskii, Glushkova (eds.) 2014]. The authors define the territory as an object of study and management based on a comprehensive analysis of the structure of the Russian economic complex. Methods of substantiating the location production were reviewed, the most important inter-sectoral complexes and sectors of the economy were characterized, and various forms of territorial organization and resettlement shown. Studies on the clustering of the regional economy are highly valuable. In general, the territorial approach convincingly shows the "region" in the system of the spatial national economy.

The same direction is shown in the study [Kurnyshev, Glushkova 2016], namely the development of theories regarding the distribution of productive forces and the territorial organization of the economy. Research on the characteristics of the productive forces' location and the territorial organization of the Russian economy is of great importance. The predicted patterns of the distribution of economic, social and natural objects based on the territorial economy organization are indicated. The practice of locating the productive forces and the laws of the territorial organization of the Russian economy are shown.

It should be emphasized that the territorial approach in the economic space is used in many well-known scientific works and studies. Traditionally, in the majority of scientific studies about regional development, two approaches are used, administrative-economic and reproduction. The authors pay close attention to the reproduction approach and conclude that the region "is not only a subsystem of the country's socio-economic complex but also a relatively independent part of it with a complete reproduction cycle, special forms of manifestation of reproduction stages and specific features of the course of social and economic processes" [Marshalova, Novoselov 1988, p. 14].

In recent years, interesting work about the practical problems of regional development, the balance of regional reproduction, and the socio-economic aspects of increasing the regional production efficiency has appeared. Even more scientific research is addressed to the theoretical understanding of economic reality, the development of ways to bring the regions out of the reality of sanctions and crisis, accelerate business practices and economic reform. For the first time, scientists are paying proper attention to the innovative direction of economic reforms. In many works, especially those regarding anti-crisis programs' analyses, most of the authors refer to this aspect.

For example, on interregional level, new horizons had been opened up regarding a number of firms and centres for mastering and introducing fundamentally new types of equipment and technology, including assisting medium and small enterprises in the reconstruction and technical re-equipment of production.

It has become possible to fully load automated lines and robotics, a joint operation of the most accurate measuring instruments and computer centres. It is achievable to develop interregional enterprises which construct engineering networks and 
communications, environmentally protected sites, sports venues, recreation centres, and construction industry facilities, and to organize specialized enterprises for the development of vegetable growing, processing of agricultural products and their storage, to develop other types of production that cannot be created by one region.

Therefore all these issues require finding optimal solutions in areas such as innovation, the interaction of economic (material) and technological (digital economy) resources at regional and national levels. In these conditions there is a need for the interaction of national and global agents and players of various kinds and scale.

The advantages, as well as the disadvantages, in the development of a regional spatial economy highlighted the problems of growing globalization, which strengthens the interaction of competing and changing parameters and its place in the international division of labour. The models and tools used in modern economic theory should contribute to a real 'reconciliation' of the concepts of different forms and important meanings, and scientific programs for the development of heterogeneous regional spatial systems. This most important task can be successfully implemented at the level of research on spatial interdisciplinary synthesis.

\section{An interdisciplinary approach to research on regions}

This approach is based on an understanding of the genesis of various disciplines, the boundaries of which are systematically modified, as well as the nature of relations with other scientific disciplines, including the social science system as a whole. The denomination "the region" came to other branches of science from geography. At the beginning of the 20th century, regions became the main object of study, firstly physical, and then economic and social geography. At the same time, the first attempts to classify regions appeared. However, regionalist-geographers did not have a single approach to the definition and topology of regions. The first typologies dividing regions into physical and natural appeared as a result of that. Physical regions were explored with knowledge related to human activity, but natural regions were studied as natural habitats of particular species, flora and fauna.

Economic geography achieved the most noticeable results in solving the issues of regional socio-economic development. Economic geography, turned into socio-economic and political by its development, has proved that it is really prepared for comprehensive research on the territorial organization of society. Socio-economic geography has a wide experience of analysis, synthesis, forecast within a comprehensive study of the interaction of nature, economy and population in regional systems.

The main results of economic and geographical research on the problems of regional development and their economic independence were obtained in studying the role and place of the region in the system of settlement and the territorial distribution of productive forces. It is the economic and geographical analysis of 
changes in the scale and specifics of production location, characteristics and interrelations of the resettlement process in modern conditions, relations and contradictions between the artificial and natural environment, highlighting the most poorly studied political and social factors interacting for the development of the region, which opens promising ways for the development of these disciplines in a globalizing environment.

Determining the role and place of the regions in the system of settlement and the location of the productive forces in it, made it possible to obtain the correct theoretical and methodological conclusions in the development of the problems and tasks for the specialization of regions. In recent years, in Russia there have emerged independent sectors intensively exploring the regions: recreational geography, geography of the service sector, geography of the life-style and life quality, geography of consumption, geodemography. Publications on the geography of training and education have appeared.

Political sciences pay significant attention to the study of regional development. Case studies began in 1990, and they are devoted to regionalization, regionalism and cross-border cooperation. It is very important that the research is carried out on a large extensive material, comparative analysis and comparative concepts that exist in the Western and domestic sciences.

Political scientists objectively justify the choice of the regional dimension of European integration at the level of specific regions. The studies comprehensively examine the processes of the birth of regionalism using the example of specific national systems and states, political institutions, and highlight important processes that have a direct impact on regionalization.

Among the major works one should note "Regional policy in market economy countries" [Larina, Kiselnikov 1998]. The authors pay great attention to the methodological aspects of regional policy, methods and tools for its implementation, the organization of tax systems and the grounding of regional decision-making. Published in 2006, the textbook "Political Regionalism" is a comprehensive study on the problems of country regional development [Busygina 2006], andone of the chapters is dedicated to European regionalism. The theoretical and practical studies of the regional development in the European Union in the context of globalization and internationalization of political processes are shown.

"Political Regionalism" by R.F. Turovskii is significant in Russian political science. The theory and methodology of political regionalism, written based on a huge array of scientific material, is a valuable contribution. The material about the territorial-state construction and modelling of the state as a territorial-political system is of interest, as are the author's studies on the very important and long-distorted problem of the Russian system development in the context of "centre-regions". The author shows how the regional structure and regional policy function in the relations "centre-regions", taking into account the modern conditions of political 'constellation' changing in the Russian regions. He considers political regionalism as 
a spatial change of the political phenomena, but regions as part of the state territory in which the political process takes place at subnational level [Turovskii 2006].

Original research on the problems of political regional studies was conducted by the St. Petersburg School of Regional Studies. In the work "International Regional Studies" on the extensive material of political science, philosophy, sociology, economics and cultural studies, he examines the current problems of international regional studies. The presented interdisciplinary analysis is of great value in didactic and scientific plans. This is probably the first scientific work, which, based on an interdisciplinary approach, shows a set of questions about the nature of political power in regions at different levels and a whole range of regionalization and globalization problems in various spheres of public life. Material about international regional conflicts, including separatist parties and movements, is very valuable. The author also cites examples of managerial decision-making by regional authorities in crises [Barygin 2009].

Sociologists have been actively involved in regional issues. In the 21 st century, the famous French academic Frederic Le Play put forward a formula that: "the place determines the working conditions". Labour affects the family organization, and the family is the social unit that forms the public. For the sociological science of that time, Le Play's interpretation of social life contributed to the integrated consideration of social issues and allowed to introduce certain differences in the development of each regional community. The social factors such as place-work-people, now show the importance of each region in the social development of the whole of society. Hence the following factors that confirm this importance and the uniqueness of the region are the factors of 'sociologization' of the population, its traditions and culture [Le Play 2012].

However, sociologists still have considerable disagreements about regional issues. In the author's opinion, the problem lies in the fact that sociologists, in trying to give a general theoretical definition of a region, are looking for clear distinctions, and then explain the connection between the concept of "region" by itself and the population of the region. In other words, sociology still does not have any consensus regarding the general social studies of the region, and, consequently, its specific social functions (the main differences between people and the region) are interpreted differently in the literature, and in some works are completely absent. In the methodology of sociology, as long as there is no strict distinction between the concept of a region-material production and a region represented by its main consumer a human being - questions in future research cannot be avoided.

The demographic situation is very important while determining the economic self-sufficiency of the regions. Regional conditions for the demographic processes vary. To this should be added the problem of the uneven distribution of the population in the regions and its spatial mobility, in order to obtain the range of problems that demographic science is investigating today.

Over recent years, demography has made a great contribution to research on population reproduction in regions. It is particularly important that in studies on the 
dependence of population reproduction, the specifics of the socio-economic and natural conditions in which these processes take place are shown, modern research on population movements is also of great interest. For example, the natural movement of the population shows the marriage and divorce rates in the context of the Russian Federation population. The fertility and mortality trends in the regions allows to calculate the needs and capacities of educational and medical institutions, in order to predict the use of labour resources.

Mechanical migration in the regions makes it possible to investigate and forecast the totality of all the territorial movements of the population, which further helps to predict the pattern of settlement: density, seasonal and pendulum mobility, the number of all the migration flows.

Regional studies on the social movement of the population are of no lesser interest. Of particular value is research on the relationship of population reproduction and changes in the social structure, i.e. transitions of people from one social group to another.

Moreover, the problem of unemployment has recently arisen. In this regard, demographers are developing theoretical and methodological recommendations for managing demographic processes and the effective employment of the population at regional level. As a result, issues regarding the optimization of the parameters of natural population movement, gender and age structure, the optimal number of children in a family, mortality and life expectancy, improvement of public health, migration processes and other problems are being considered. Demographic science research on the balance of population reproduction has practical importance in searching for the most effective ways of regional socio-economic development in the new conditions of economic globalization.

A large contribution to modern research on the regions is made by the urban planning branches of science, and this is no mere coincidence. If for economic disciplines, socio-economic geography, political science, sociology, any settlement or territory appears only as one of the objects for their research, then for urban planning they are the unique ones. Urban sciences have developed an approach to a locality as a whole, which requires the proportional and interrelated development of all its elements.

For example, urban sciences explore the integrated development of architecture and construction based on comprehensive approaches, basic requirements and standards in functional, practical, economic, demographic, construction, technical, sanitary and hygienic, aesthetic, architectural and artistic areas.

Recently, the specificity of urban factors has become much more complicated. If earlier in the region the settlement consisted of several separate areas (according to the scheme "an enterprise-residential settlement near it"), now in most regions the growth of enterprises is limited due to the lack of available territories and the threat of environmental degradation. At the same time, residential areas near enterprises have exhausted their territorial resources, which forces them to settle personnel 
further and further from production. Obviously, the problem of locating numerous small enterprises (construction, transport, utilities, etc.), which occupy the corresponding areas of urban land, has been added to this, thereby introducing additional problems to the solution of planning questions.

Urban planning sciences solve these problems taking into account the specifics of a particular region. They identify functional planning units on the basis of the spatial localization analysis of the various settlements - functions that affect the population livelihoods and find the most rational options for solving them.

Together with other scientific disciplines, ecology takes an active part in studying the problem of regions. Recently, among scientists from different disciplines, the focus on environmental issues has significantly increased. This is explained by the fact that the population's civic position about environmental issues has been enhanced nowadays. Today there is no region where the increasing scale of environmental pollution does not alarm people. That is why biologists, geographers, representatives of economic disciplines, and scientists of other specializations are trying to find the best way out of a difficult situation. However, for specific regions, many problems are not sufficiently substantiated by science. Further research on the environmental problems of the regions requires deep professional, theoretical, methodological development of the human-natural environment interaction problems, which undoubtedly will improve the practice of the new economic mechanism, and implement the necessary environmental measures, especially in those regions where environmental problems have become sharply aggravated. Thus interdisciplinary studies show that the modern region acts as a holistic functioning mechanism where full cycles of human reproduction and life are carried out.

\section{Conclusion}

It should be emphasized that the accumulated problems of the regional socio-economic development once again discuss the necessity of deep spatial and interdisciplinary research based on the findings of all engaged scientific disciplines. Today, some conclusions already can be used in determining the place of regions in a globalizing economy.

For example, economic disciplines characterize the region as spatial, socio-economic integrity, where the main processes of material production take place and the integrity of the reproduction base is preserved. Socio-economic geography defines it as an object mediated by production, or as an environment in which a person interacts with material production. Demography explores the region as a living environment that creates conditions for the reproduction of the population. Urban-planning branches of science study it as a unified whole that requires the proportional and balanced development of all elements. The region is interesting for ecology as an economic territory affecting the natural environment. 


\section{Bibliography}

Barygin I.N., 2009, International Area Studies, Piter, Sankt Petersburg.

Biiakov O.A., 2004, The Theory of Economic Space: Methodological and Regional Aspects, Tomsk State University, Tomsk.

Busygina I.M., 2006, Political Regionalistic, Moscow State Institute of International Relations, ROSSPEN, Moscow.

Christaller W., 1933, Die zentralen Orte in Süddeutschland, Gustav Fischer, Jena.

Hayek F.A., 2008, The Fortunes of Liberalism: Essays on Austrian Economics and the Ideal of Freedom, Liberty Fund Inc.

Heilbroner R.L., 1999, The Worldly Philosophers: The Lives, Times and Ideas of the Great Economic Thinkers, Seventh Edition, Touchstone by Simon \& Schuster.

Hägerstrand T., 1952, The propagation of innovation waves, Lund Studies in Geography, Series B, no 4. Hägerstrand T., 1967, Innovation Diffusion as a Spatial Process, University of Chicago Press, Chicago. Iakovleva A.E. (ed.), 2010, Basics of the Regional Economy, Paleotip, Moscow.

Kurnyshev V.V., Glushkova V.G., 2016, Regional Economy. Fundamentals of the Theory and Methods of Research, $3^{\text {rd }}$ edition, revised and extended, KNORUS, Moscow.

Larina L.I., Kiselnikov A.A., 1998, Regional Policy in Market Economy Countries, Moscow.

Le Play F., 2012, The Basic Constitution of the Human Race. Ideas, Manners and Institutions of Prosperous Nations, Librikon, Moscow.

Limonov L.E. (ed.), 2014, Regional economy and spatial development, [in:] Regional Economy. Theory, Models and Methods, Urait, Moscow.

Lösch A., 1940, Die räumliche Ordnung der Wirtschaft, Gustav Fischer, Jena.

Marshalova A.S., Novoselov L.S., 1988, Fundamentals of the Theory of Regional Reproduction, Ekonomika, Moscow.

Perroux F., 1950, Economic space theory and applications, Quarterly Journal of Economics, vol. 64, no. 1, pp. 89-104.

Plisetskii E.L., Glushkova V.G. (eds.), 2014, Regional Economy, Urait, Moscow.

Physical Encyclopedic Dictionary, 1965, V. 4, Sov. Encyclopedia, Moscow.

Turovskii R.F., 2006, Political Regionalistic, Higher School of Economics, Moscow.

Thünen J.H., 1826, Der isolirte Staat, Higher School of Economics, Hamburg.

Weber A., 1909, Über den Standort der Industrie. Reine Theorie des Standorts, Mohr, Tübingen. 